\title{
Environmental education as a priority in education of a contemporary man*
}

\author{
Edukacja ekologiczna priorytetem wykształcenia współczesnego człowieka
}

\author{
Elżbieta Buchcic \\ Institute of Biology, Jan Kochanowski University of Humanities and Sciences, Poland \\ ORCID: https://orcid.org/0000-0002-2391-6340• elzbieta.buchci@@ujk.edu.pl
}

\begin{abstract}
People never stop learning and developing their skills. Education is associated with different spheres and different moments of people's lives. The learning process is mainly linked with schools, however, we should not underestimate that process which takes place outside schools as well. What we have learned, contributes, to a great extent, to what sort of people we are. The more we know, the more aware of the nearby World development, the more aware of phenomena understanding, phenomena that take place around us and, therefore, allow us to participate in all society activities.
\end{abstract}

Keywords: education, non-formal education, environmental education, ecological education, mass media

Streszczenie: Ludzie nigdy nie przestaną się uczyć i rozwijać swych umiejętności. Edukacja łączy się z różnymi sferami i momentami życia człowieka. Choć uczenie się związane jest głównie z pracą szkoły, nie powinno się nie doceniać procesu kształcenia dokonującego się także poza szkołą. To, czego się nauczyliśmy w wielkim stopniu wpływa na to, jakimi ludźmi jesteśmy. Im więcej wiemy, im bardziej świadomi jesteśmy, jak rozwija się świat, tym lepiej rozumiemy zjawiska dokonujące się wokół nas, a przez to stajemy się zdolni do pełnego uczestnictwa w życiu społeczeństwa.

Słowa kluczowe: edukacja, edukacja nieformalna, edukacja środowiskowa, edukacja ekologiczna, środki masowego przekazu

Human being, as a biopsychosocial entity, in the course of his or her development manifests certain activity and is influenced by the environment in which he or she lives and acts. One of the forms of human activity is education, which results in a certain level and character of the awareness of the human being and its culture.

J. Frątczak

\section{Introduction}

Nowadays, the concept of education is very common. However, formal education, i.e. the kind of education that everyone had to deal with at school, during university studies and as part of various types of training, cannot be the only source of education for us. This is because the knowledge that we can use in our everyday lives as well as the knowledge that we acquire most willingly is the one that matters most. And this is where non-formal education comes in. Modern man is subjected to it nearly every- where. Shaping of attitudes, values, skills and knowledge is a life-long process. Various experiences and educational impact of the environment, including mainly family,

"This article was originally published in Polish as Buchcic, Elżbieta. 2009. „Edukacja ekologiczna priorytetem wykształcenia współczesnego człowieka." Studia Ecologiae et Bioethicae 7(1): 203-211. The translation of the article into English was financed by the Ministry of Science and Higher Education of the Republic of Poland as part of the activities promoting science - Decision No. 676/P-DUN/2019 of 2 April 2019. Translation made by GROY Translations. 
work environment and mass media, shape our character and the way we will perceive the world.

In the modern world, mass media are very widespread and play a huge role in educating society. By means of television, radio and the Internet it is possible to present the environment and its problems in an interesting way.

A very important advantage of such knowledge acquisition is that everyone can choose relevant TV programs, radio programs and websites to broaden their individual interests. There is no specific format imposed nor there is any particular person who provides predefined information. It should also be remembered that not everyone has an equal chance to acquire knowledge through the formal education system. Non-formal education in a certain way complements the formal education system. It levels the playing field for those who did not have the opportunity to complete the full programme of education in the formal education system.

Naturally, there are also disadvantages of non-formal education. These include mainly the reliability and credibility of the information provided, the lack of formal recognition, as well as the costs related to the access to particular forms of mass media.

It would seem that local environmental issues should be of great interest to the public. But is this the case? More and more often, problems of nature are being pushed into the background, and not much attention is paid to them. A man never stops learning and developing. Education accompanies us in different spheres and moments of life. We associate education mainly with the school, but we should not neglect learning that takes place outside its walls. What we learn contributes greatly to what kind of people we are. The more knowledge we have, the greater is our awareness of the development of the world around us, our understanding of the phenomena that take place around us, which in turn allows us to participate fully in society.

\section{Education and environmental awareness}

Man, like any living organism, is part of the environment and subject to its laws. Ecology is the science of relationships, interdependencies between organisms and the environment around them. The term "ecology" comes from the Greek words: oikos, which means home, environment, and logos - word, science; therefore, ecology literally means the science of where organisms live. This term was first introduced in 1869 by the German zoologist Ernst Haeckel" (Tuszyńska 2006, 18).

"The degree of environmental degradation that has occurred in recent decades has drawn the attention of the public opinion of many societies to problems related to the effects of uncontrolled development of civilization. The deteriorating state of the environment requires a broadly understood environmental education of all social and professional groups" (Parlak 2005, 9).

"Environmental education refers to the subject of teaching and educational activities that prepare for solving practical environmental problems through an interdisciplinary approach, a sense of responsibility and active involvement of each individual and community in common action" (Olaczek 1999, 61).

"Ecological (environmental) education is a concept of education and upbringing in the spirit of respect for the natural environment and shaping the views of society towards the surrounding world. It concerns stimulating sensitivity to environmental problems, searching for causes and predicting the effects of phenomena leading to environmental degradation" (Tuszyńska 2006, 5).

A human being is inextricably connected with nature and all his activities are reflected in the environment around us. It is therefore important to make the public aware of the possibilities and ways of functioning and enjoying the benefits of nature with the least damage possible. This kind of human activity is referred to as sustainable development in the literature. It consists in "conducting all business activities in harmony with nature, that is to say, in such a way as not to cause irreversible changes 
therein" (Cichy 1995). It is also necessary to demonstrate the farsightedness of these actions, as the environment is used not only by ourselves, but also by future generations.

„(...) There are three main areas that need to be focused on when planning an effective strategy for achieving sustainable development. These are: environmental protection and rational management of natural resources (e.g. reduction of environmental pollution, protection of endangered animal and plant species, promotion of renewable energy sources), economic growth and fair distribution of benefits arising therefrom (i.a. facilitating market access for developing countries, development financing, changing irrational patterns of consumption and production) and social development (i.a. combating poverty, access to education, health care)".

In order for life on Earth to survive, it is essential to develop environmental awareness. "The dissemination of environmental awareness in society is a prerequisite for sustainable development. Environmental awareness should be fostered by environmental education and universal education in the field of environmental protection, carried out by educational system at various levels, social organisations and institutions and the media" (Kaliński 1995).

"Ecological awareness, understood as an area of social awareness related to the natural environment, manifests itself both in thinking and experiencing and in social standards of understanding, experiencing and valuing the biosphere. The components of environmental awareness include specific contents, attitudes and emotions concerning the natural environment, linked and intertwined with other forms of social awareness". According to H. Skolimowski, environmental awareness should be: (Parlak 2005, 13)

- holistic - the world around is understood as a whole to which a human being also belongs and that has the characteristics of a living organism

- qualitative - it sees the unity and inextricability of the world as primarily a qualitative relationship,
- spiritual - related to the spirituality of the human being and not only to his or her mind,

- referential - characterized by the reverence and respect for everything that exists,

- participatory - human beings actively participate in the life of our planet and are not passive observers,

- evolutionary - "the course of processes in the cosmos is oriented from uniformity to diversity, from materiality to spirituality, so the evolution of the cosmos - as a whole that is accessible to human cognition - presents the phenomenon of the spread of mental and spiritual processes."

"Environmental awareness is based on knowledge acquired in and outside school, the cultural tradition of a particular social group, pressure of that group's opinions, own experiences, etc. The content of ecological awareness includes, among others: human rights to the environment, knowledge of threats, their causes and effects, sense of own responsibility for the condition of nature, willingness to act combined with the belief that nature is worth protecting" (Tuszyńska 2006, 8).

Awareness-raising work will create an ecological culture of the individual, which will consist of the following elements: (Cichy 1995, 278)

- overall environmental knowledge,

- the ability to perceive the specificity and complexity of natural phenomena and identify the main phenomena, interdependencies and regularities therein,

- willingness to manifest certain behaviours towards the environment,

- the ability to think openly and creatively and to be susceptible to innovations that guarantee greater environmental safety,

- developing the sensitivity and ability to perceive environmental problems in one's own work and life."

\section{Factors shaping the ecological society}

Raising public awareness and involvement in environmental activities creates the attitudes, values and necessary skills needed 
to put the principles of sustainability into practice on a daily basis.

According to Dołęga, the educational issues of ecophilosophy relate primarily to the philosophical foundations of pro-ecological education, and more specifically to sozological education in the family, at school, in the mass media, in social organisations, religions and general national education.

Shaping awareness that is sensitive to the value of the social and natural environment also depends on the curricula in kindergartens, primary schools, upper-secondary schools and universities and on the general environmental education of adults.
Moreover, it is a priority task for all those who are aware of the quality of the current environment, its impact on the life on our planet, as well as its impact on human life and health in our homeland and around the world. This is not just a task for philosophers, but for all those who influence social awareness in Poland and worldwide (Dołęga 2003, 35-36). As commonly understood, these are all forms of activity aimed at society, with particular emphasis on children and young people, which are intended to influence the level of ecological awareness, to promote specific behaviours beneficial to the natural environment and to disseminate knowledge about nature.

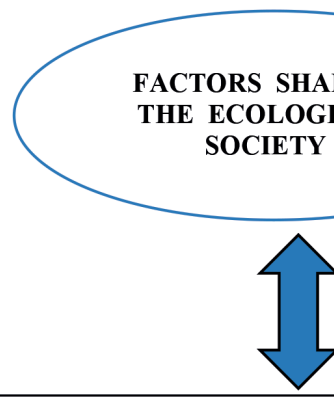

\section{School education}

- Environmental education within the formal education system

- Preschool education

- Primary and secondary schools

- Higher education

\section{Adult education}

- Central institutions and offices

- Environmental education in provinces

- Environmental education in local governments

- Admnistration of areas of high natural value

- Leisure and tour operators

- Social organisations

- Churches and Religious Organizations

- Environmental education in the workplace

- Environmental education in the family

- Media

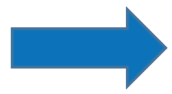

Formal education

School education should provide the basis for continuous, life-long learning on sustainable development

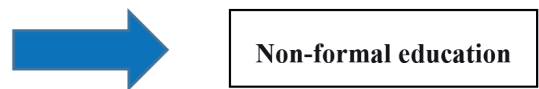

Continuing education 


\section{Factors influencing the effectiveness of environmental education:}

- $\quad$ promoting the most effective forms and the most important

- content, indication of ways to optimise the allocation of financial resources,

- organising the flow of information and streamlining the decision-making process related to education.

These objectives should be achieved using the best domestic and foreign experience.

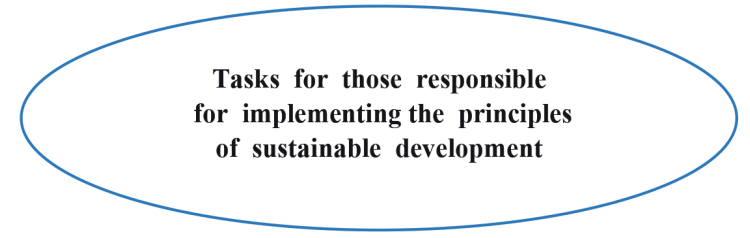

Family

- positive behavioural patterns in line with the principles of sustainable development in everyday life, e.g.: waste segregation, saving water and energy, respect for nature

- enabling children to develop interests related to environmental protection, in cooperation with social organizations and local governments

- $\quad$ shaping the right ecological attitudes.

Authors and publishers of non-serial publications related to the development of environmental education.

- a wide range of materials that have been properly designed in terms of methodology and content

- apt and easily accessible offer

- practical information based on the authors' teaching experience

- texts supplemented with sets of charts, films, electronic records, computer programs, etc.

\section{Field educators}

- implementation of programmes that make strict use of the advantages and possibilities of a given area

Classes should be:

- planned but allow for spontaneous discoveries when formulating questions and grouping problems

- thematically diverse with natural, historical, aesthetic and even personal references

- encourage individual, direct investigation of the landscape to ensure organisational

\section{Clergymen and catechist}

- $\quad$ providing independent education related to the principles of faith

- the teaching should draw on models of moral responsibility for words and deeds and on the axioms of goodness and love

- $\quad$ using the experience arising from the spirit of ecumenism, affirmation of live

Employees of the police, municipal police, fire brigade, forest service

- environmental education integrated into the service curriculum

- constant supervision of shaping the correct ecological image of the place and the actions taken in the field

- compliance with environmental regulations

- $\quad$ specially prepared publications. brochures containing the necessary information

\section{Radio editors}

- regional news compiled in cooperation with local organisations and individual environmental protection groups

- $\quad$ authenticity, encouragement to act and learn about nature

- good advice and conversations with people involved in this issue

- $\quad$ searching out famous and widely respected people with ecological interests

Employers

- permanent information on the activities of the institution's management bodies in the field of improving the ecological image of the company with social and economic reasoning

- $\quad$ paying attention to trends beneficial to the environment and employees

- $\quad$ exposing the actual existing environmental problems associated with the company's operations

- organisation of mass events, introduction of clear ecological accents

- the pursuit of economic gains without environmental damage 


\section{Publishers and editors of periodicals}

- $\quad$ articles of the highest quality from good journalists

- presentation of famous people working for the environment

- beautiful photographs of nature, which promote the Polish landscape in particular

- competitions for different social and professional groups

\section{Publishers and editors of daily newspapers}

- reliable information free of sensationalism

- $\quad$ series that promote the expected pro-ecological behaviour in society

- scientific and popular science information on the issues of environmental protection and formation

- promoting regional and local initiatives to implement sustainable

- development thematic series that will win regular readers

\section{TV editors}

- reliable information in journalistic programmes

- programmes should only contain a presentation and possibly a serious factual discussion

- presenting balanced comments

- attractive journalistic and nature programmes, movies, video clips that address the most interesting environmental issues with humour, but also with reflection

- abandonment of reportages that expose conflicts instead of the substance of the matter nature

- movies with original, informative commentaries prepared by specialists

\section{Civil servants}

- the principles of sustainable development should be known to all government and local government employees

- knowledge should be continuously enriched and used for various types of professional contacts, as well as for making and justifying decisions

- $\quad$ sound knowledge of regional and local environmental problems

- in terms of organisation, it is important to be able to use the civil servants in the process of environmental education of the society

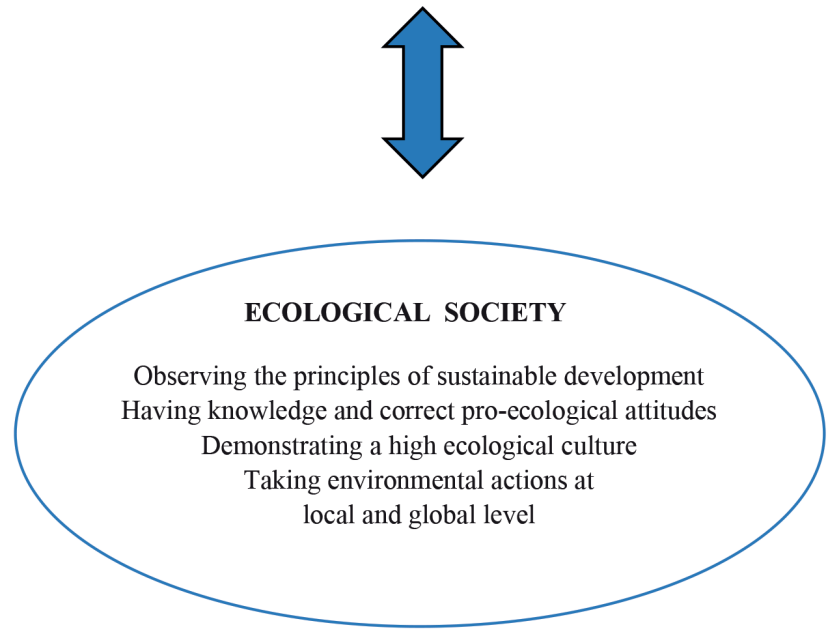

Fig. 1. Factors shaping the ecological society 
It is important to create a system of environmental education that integrates environmental issues with traditional sciences. Such curricula should be developed, e.g. on green business management, which are interdisciplinary and practicable for the country concerned.

\section{Conclusion}

The knowledge-based economy creates favourable conditions for the creation and absorption of information through the development of innovation and education (education system).

As a result, Poland must define and improve its education policy. This improvement will be achieved by, among other things, imposing an obligation on universities to appoint business representatives as members of university authorities and academic committees.

This will create a set of incentives for recruiting, retaining and promoting qualified staff from outside universities (Bank Swiatowy 2004, 82-83).

It will not be easy to awaken in man, such responsibility for the world that will keep pace with the development of civilization.

But those who want can start today. Vaclav Havel

\section{Bibliography}

Bank Światowy. 2004. Polska a gospodarka oparta na wiedzy - w kierunku zwiększenia konkurencyjności Polski w Unii Europejskiej. Warszawa: Bank Światowy Region Europy i Azji Środkowej - Departament Rozwoju Sektora Prywatnego i Finansowego.

Cichy, Danuta. 1990. „Koncepcje społecznej edukacji ekologicznej." Biologia w Szkole 211(5): 278-285.

Cichy, Danuta. 1995. „Skuteczność kształcenia dla ekorozwoju." Biologia w Szkole 48(5): 236-240.

Dołęga, Józef M. 2003. „Z filozofii nauk ekologicznych." W Ochrona środowiska społeczno-przyrodniczego $w$ filozofii $i$ teologii, red. Józef M. Dołęga, Jacek W. Czartoszewski, Antoni Skowroński, 25-37. Warszawa: Wydawnictwo UKSW.

Kaliński, Mirosław. 1995. „Edukacja ekologiczna formą przystosowania obronnego." Edukacja i Dialog 69(6): 46-54.

Olaczek, Romuald. 1999. Stownik szkolny. Ochrona przyrody i środowiska. Warszawa: Wydawnictwa Szkolne i Pedagogiczne.

Parlak, Mirosława. 2005. Edukacja ekologiczna $w$ procesie ksztatcenia wczesnoszkolnego założenia, program, propozycje metodyczne. Kielce: Wydawnictwo Pedagogiczne ZNP.

Tuszyńska, Ligia. 2006. Edukacja Ekologiczna dla nauczycieli i studentów. Warszawa: Wyższa Szkoła Pedagogiczna Towarzystwa Wiedzy Powszechnej. 